\title{
Comparison of Antioxidant Properties of Wild Blueberries (Vaccinium arctostaphylos L. and Vaccinium myrtillus L.) with Cultivated Blueberry Varieties (Vaccinium corymbosum L.) in Artvin Region of Turkey
}

\author{
Özlem Saral ${ }^{1}$, Zafer Ölmez ${ }^{2}$, Hüseyin Şahin ${ }^{3}$ \\ ${ }^{1}$ Department of Nutrition and Dietetics, College of Health, Artvin Çoruh University, 08000 Artvin, Turkey, \\ ${ }^{2}$ Department of Forest Engineering, Faculty of Forestry, Artvin Çoruh University, 08000 Artvin, Turkey, \\ ${ }^{3}$ Espiye Vocational School, Giresun University, 28600, Espiye/Giresun, Turkey.
}

\section{A R T I C LE IN F O}

\section{Article history:}

Received 05 May 2014

Accepted 21 July 2014

Available online, ISSN: 2148-127X

Keywords:

Vaccinium sp.

Antioxidant activity

Wild blueberry

Cultivated blueberry

Polifenol

Corresponding Author:

E-mail: otarhan@artvin.edu.tr

\section{A B S T R A C T}

Vaccinium arctostaphylos L. and Vaccinium myrtillus L. which are found naturally in most part of Blacksea Region, and Artvin are generally called bear grape, Trabzon tea, and likapa. In addition, different varieties of blueberry (Vaccinium corymbosum L.) have been cultivated in Artvin region for 5 or 6 years. Blueberries contain appreciable levels of phenolic compounds, including anthocyanins and flavonols that have high biological activity. V. arctostaphylos and $V$. myrtillus show that natural distrubition with received $V$. corymbosum of different cultured species in Artvin region will be determined antioxidant activity in this study. In this study showed that wild species had a higher antioxidant effect than cultivated species. V. myrtillus had high total polyphenols (11.539-20.742 mg GAE/g dry sample), flavonoids (1.182-2.676 mg QE/g dry sample) and anthocyanins (3.305-11.473 $\mathrm{mg}$ Cyn/g dry sample) than $V$. corymbosum species. In addition, wild species had high CUPRAC, FRAP and DPPH values. The antioxidant activities found with CUPRAC, expressed as trolox equivalent antioxidant capacity ranged from 0.143 to $0.297 \mathrm{mmol}$ TEAC/g dry sample. Those determined with DPPH expressed as IC50 ranged from 0.229 to $1.178 \mathrm{mg} / \mathrm{ml}$. Those determined with FRAP expressed as $\mathrm{FeSO}_{4} .7 \mathrm{H}_{2} \mathrm{O}$ equivalent were in $130.719-346.115 \mu \mathrm{mol} \mathrm{Fe} / \mathrm{g}$ dry sample range.

\section{Artvin Yöresine Ait Doğal Yaban Mersini (Vaccinium arctostaphllos ve Vaccinium myrtillus) ile Kültüre Alınan Yaban Mersini (Vaccinium corymbosum) Türlerinin Antioksidan Özelliklerinin Karşılaştırılması}

M A K A L E B İ L G İ S İ

Geliş 05 Mayıs 2014

Kabul 21 Temmuz 2014

Çevrimiçi baskı, ISSN: 2148-127X

Anahtar Kelimeler:

Vaccinium sp.,

Antioksidan aktivite

Yabani yabanmersini

Kültür yabanmersini

Polifenol

"Sorumlu Yazar:

E-mail: otarhan@artvin.edu.tr

\section{Ö Z E T}

Karadeniz Bölgesi'nde ve Artvin'de doğal olarak bulunan Vaccinium arctostaphylos L. ve Vaccinium myrtillus L. genellikle ayı üzümü, Trabzon çayı ve likapa olarak adlandırılmaktadır. Ayrıca Artvin'de 5-6 yıldır yaban mersininin farklı türleri (Vaccinium corymbosum L.) yetiştirilmektedir. Yaban mersinleri yüksek biyolojik aktiviteye sahip antosiyaninler ve flavonoller gibi dikkate değer seviyede fenolik bileşenler içermektedir. Bu çalışmada Artvin bölgesinde doğal yayılım gösteren $V$. arctostaphylos ve $V$. myrtillus ile kültüre alınan $V$. corymbosum farklı türlerinin antioksidan aktiviteleri belirlenecektir. $\mathrm{Bu}$ çalışmada yabani türlerin kültürlere göre daha yüksek antioksidan etkiye sahip olduğunu görüldü. V. myrtillus türleri, $V$. corymbosum türlerinden daha yüksek toplam polifenol (11,539-20,742 mg GAE/g kuru örnek), flavonoid (1,182-2,676 mg QE/g kuru örnek) ve antosiyanin (3,305-11,473 mg Cyn/g kuru örnek) değerine sahiptir. Ayrica yabani türler yüksek CUPRAC, FRAP ve DPPH değerlerine sahiptir. Antioksidan aktiviteler CUPRAC için Troloks eşdeğeri cinsinden 0,143 -0,297 mmol TEAC/g kuru örnek aralığında bulunmuştur. DPPH için IC50 değerleri 0,229 - 1,178 mg/ml kuru örnek aralığında belirlenmiştir. FRAP için $\mathrm{FeSO}_{4} \cdot 7 \mathrm{H}_{2} \mathrm{O}$ eşdeğeri cinsinden $130,719-346,115$ $\mu \mathrm{mol} \mathrm{Fe/g} \mathrm{kuru} \mathrm{örnek} \mathrm{aralığında} \mathrm{bulunmuştur.}$ 


\section{Introduction}

Dark purple fruit of species Vaccinium sp. are multiyear plants and cultured plants species are on economic life of the 35-40 years. Vaccinium species generally were distributed different regions in North America, Europe and Asia. Vaccinium arctostaphylos and Vaccinium myrtillus are generally found in Artvin, Rize, Trabzon, Giresun and Ordu, in Turkey and offer a variety of wildlife. In recent years, growing blueberry has become popular, owing to the increasing international demand for its berries (Çelik, 2004; Gümüş et al., 2009)

Blueberry with a low amount of calories and sodium content are free cholesterol and an excellent source of fiber. Blueberry has pectin agent lowering blood sugar. Because of these properties of Vaccinium species are grown everywhere in the world where the climate is suitable (Çelik, 2005).

Blueberry is a fruit that has the high antioxidant capacity and includes phenolic compounds. In addition, it has anthocyanins having high biological activity, and includes flavonols. Anthocyanins have protective effect against chronic diseases such as cancer, cardio and cerebrovascular diseases, atherosclerosis and diabetes and possible benefits in terms of health linked to capacity of high antioxidant ( $\mathrm{Wu}$ et al., 2002). According to the analysis carried out on small-grained many fruits, wild blueberries the capacity to absorb oxygen radicals tend to have the highest antioxidant effect (Atalay et al., 2003).

In the previous studies have been shown to be different antioxidant content of wild and cultivated blueberies (Riihinen et al., 2008; Bunea et al., 2011; Koca and Karadeniz, 2009). But there was not any research which belonged to Artvin region. The aim of the present study is to determine and compare total phenolic content, total flavonoid content, total anthocyanin content and antioxidant activity of native ( $V$. arctostaphylos and $V$. myrtillus) and cultivated (V. corymbosum cv. Patriot, V. corymbosum cv. Bluecrop, V. corymbosum cv. Darrow, $V$. corymbosum cv. Brigitta and $V$. corymbosum cv. Blujay) blueberry fruits of Artvin.

\section{Materials and Methods}

The fruits of $V$. arctostaphylos were collected from four different regions (Artvin-Sacinka, Borcka-Efeler, Borcka-Efeler-Blueberry Hill, Borcka-Findık Yaylası) and $V$. myrtillus fruits were collected from Borcka-Findik Yaylas1 in Turkey. The fruits of $V$. corymbosum were collected from cultivated fields in Hopa-Kemalpaşa, in Artvin.

Collected ripe fruits were stored at $-20^{\circ} \mathrm{C}$ until the analysis. The fruits dried in the oven at $40^{\circ} \mathrm{C}$ before treatments. Approximately $10 \mathrm{~g}$ of dried sample of the fruits was used preparing methanolic extracts for each specis and cultivars. These preparations were used determining antioxidant activities, and the treatments were done with 3 replications.

Spectrophotometric methods was used on total anthocyanins, total polyphenols, total flavonoids and antioxidant tests. Spectrophotometric methods are frequently used for standardization of natural raw materials.

\section{Total Phenolic Assay}

The total phenolic content of fruits were determined by using the Folin-Ciocalteu assay (Slinkard and Singleton, 1977). In this study, gallic acid (1;0.5; 0.25; $0.125 ; 0.0625$ and $0.03125 \mathrm{mg} / \mathrm{ml}$ ) was used as a standard. Briefly, $20 \mu \mathrm{l}$ of various concentrations of gallic acid and $20 \mu \mathrm{l}$ methanolic samples $(1 \mathrm{mg} / \mathrm{ml}), 400 \mu \mathrm{l}$ of $0.5 \mathrm{~N}$ Folin-Ciocalteu regents and $680 \mu \mathrm{l}$ of distilled water were mixed and the mixture was vortexed. Following 3-minute incubation, $400 \mu \mathrm{l}$ of $\mathrm{Na}_{2} \mathrm{CO}_{3}(10 \%)$ solution was added and after vortexing, the mixture was incubated for 2 hours. After the incubation period at the room temperature, absorbances of the mixtures were measured at $760 \mathrm{~nm}$. The concentrations of total phenolic compounds were calculated as $\mathrm{mg}$ of gallic acid equivalents per $\mathrm{g}$ of the dry weight of samples.

\section{Total Flavonoid Assay}

The total flavonoid content was measured by using the aluminum chloride assay (Chang et al., 2002). Quercetin was used as a standard. $0.5 \mathrm{ml}$ of Quercetin $(1 ; 0.5 ; 0.25$; $0.125 ; 0.0625$ and $0.03125 \mathrm{mg} / \mathrm{ml}), 4.3 \mathrm{ml}$ methanol 0.1 $\mathrm{ml} 10 \% \mathrm{Al}\left(\mathrm{NO}_{3}\right)_{3}$ and $0.1 \mathrm{ml} 1 \mathrm{M} \mathrm{NH}_{4} \mathrm{CH}_{3} \mathrm{COO}$ were added in test tubes and mixed. Mixtures were incubated for 40 minutes. After incubation, absorbance was measured at $415 \mathrm{~nm}$. The total flavonoid contents of fruits were expressed as $\mathrm{mg}$ quercetin equivalents per $\mathrm{g}$ of dry weight sample.

\section{Total Anthocyanin Assay}

Determinations of total anthocyanin were made with pH-differential method (Giusti and Wrolstad, 2001; Fuleki and Francis, 1968). $20 \mathrm{~mL} \mathrm{KCl}$ solution ( $\mathrm{pH} \mathrm{1)}$ was added first tube, $20 \mathrm{ml} \mathrm{CH} 3 \mathrm{COONa}(\mathrm{pH} \mathrm{4.5)}$ was added other tube and waited for about 30 minutes. In the meantime, diluted clear sample was spectrum of the 250-600 nm. At $\mathrm{pH} 1.0$ and $\mathrm{pH} 4.5$ the sample solution in the buffer solution was measured absorbance at 520 and $700 \mathrm{~nm}$ and calculated by the total monomeric anthocyanin content.

\section{Determination of Antioxidant Activity}

The antioxidant activities of the samples were determined using by FRAP, CUPRAC and DPPH methods.

The FRAP method was used for the determination of total antioxidant capacity, based on the reduction of yellow $\mathrm{Fe}^{3+}$-TPTZ complex to the blue $\mathrm{Fe}^{2+}$-TPTZ complex by electron donating substance under acidic condition (Benzie and Szeto, 1999). The $3 \mathrm{ml}$ of FRAP reagent (containing TPTZ, $\mathrm{FeCl}_{3}$, and acetate buffer) and $100 \mu \mathrm{l}$ of the test sample or the blank (solvents used for extraction) were added test tube and mixed. Maximum absorbance values at $593 \mathrm{~nm}$ were recorded for $4 \mathrm{~min}$ at $25^{\circ} \mathrm{C}$. The final absorbance was compared with the standard curve $(100-1000 \mu \mathrm{mol} / \mathrm{l})$. The data were expressed as $\mu \mathrm{mol} \mathrm{FeSO}_{4} \cdot 7 \mathrm{H}_{2} \mathrm{O}$ equivalents per gram of dry matter.

The CUPRAC method is comprised of mixing the antioxidant solution (directly or after acid hydrolysis) with a copper (II) chloride solution, a neocuproine alcoholic solution, and an ammonium acetate aqueous buffer at $\mathrm{pH} \mathrm{7,} \mathrm{and} \mathrm{subsequently} \mathrm{measuring} \mathrm{the} \mathrm{developed}$ 
absorbance at $450 \mathrm{~nm}$ after 60 minutes (Apak et al., 2004).

$1 \mathrm{ml} 10 \mathrm{mM} \mathrm{CuCl}_{2}, 1 \mathrm{ml} 7.5 \mathrm{mM}$ Neocuproine and $1 \mathrm{ml}$ $1 \mathrm{M} \mathrm{NH}_{4} \mathrm{Ac}$ were added test tubes, than $0.2 \mathrm{ml}$ sample and $0.9 \mathrm{ml} \mathrm{H}_{2} \mathrm{O}$ added and mixed. End volume was $4.1 \mathrm{ml}$. Measure final absorbance at $450 \mathrm{~nm}$. The test results obtained Trolox ${ }^{\circledR}$ equivalent antioxidant capacity (TEAC) were given.

Radical scavenging activity of methanolic extracts against 2,2-diphenyl-1-picrylhydrazyl (DPPH) radical was spectrophometrically at $517 \mathrm{~nm}$. The assay is based on the color change of the DPPH solution from purple to yellow as the radical is deactivated by the antioxidants (Pokorny et al., 2001). Briefly, various concentrations $0.75 \mathrm{ml}$ of parts of sample extracts was mixed with 0.75 $\mathrm{ml}$ of a $0.1 \mathrm{mM}$ of DPPH in methanol. Radical scavenging activity was measured by using Trolox as standards and the values are expressed as IC50 (mg or mg sample per $\mathrm{ml}$ ), the concentration of the samples that causes $50 \%$ scavenging of DPPH radical.

\section{Statistical analysis:}

The data were expressed as mean \pm standard deviation (SD) from three parallel measurements. In order to determine the significant differences between values, analysis of variance (ANOVA) and Duncan's multiple range tests were performed. Significance of difference was defined at $\alpha=0.01$.

\section{Results and Discussion}

In general, phenolic acids, flavonoids and anthocyanins are antioxidant molecules. When the value of these molecules is high, antioxidant properties of plants is high (Al-Mamary et al., 2002; Robards et al., 1999). The total anthocyanin, total phenolic content and total flavonol contents of blueberry fruits were shown in Table 1, and FRAP and CUPRAC values were shown in Table 2.

Results showed the highest phenolic content value obtained from V. arc. ebh and V. myrt $(\mathrm{P}<0.01)$. V. myrt and V. arc. sc showed the highest flavonoid contents and also V. myrt showed anthocyanins contents $(\mathrm{P}<0.01)$. Between cultivated species, the highest content of polyphenols and anthocyanins were observed Patriot, and the highest flavonoid content was observed Bluejay
$(\mathrm{P}<0.01$; Table 1). In addition to these, the fruit of $\mathrm{V}$. myrt showed maximum activity according to the FRAP and the fruits of $\mathrm{V}$. myrt and V. arc. ebh showed maximum activity according to the CUPARC $(\mathrm{P}<0.01)$. Between cultivated species Patriot has the highest activitiy at FRAP. Darrow and Patriot had also the same activity at CUPRAC $(\mathrm{P}<0.01$; Table 2$)$.

The IC50 values determined from analysis of DPPH were showed in Fig. 1. When the fruits of V. arc. ep. had the highest DPPH radical cleaning, the lowest activity was obtained from $\mathrm{Bj}$ fruits.

In general, bluberry fruits have a high antioxidant content. Its fresh and dried fruits are sold in many markets. In addition, leaves of bluberries can be found in markets as tea. According to the results of some previous researches, fruits of blueberries prevent memory lossing and aging since they includes antiageing features (Çelik, 2005). Anthocyanins, phenolic compounds and flavonoids hfave the ability to neutralize free radicals. Blueberries contain high amounts of phenolic compounds and have a high antioxidant activity (Prior et al., 1998).

According to the total polyphenols, anthocyanins, flavonoids and antioxidant activity analyses of the dry bluberry fruits, the results showed that the dry natural blueberries ( $V$. arctostaphylos and $V$. myrtillus) had a higher activity than dry cultured blueberries in the study.

Bunea et al. (2011), compared total anthocyanins, total polyphenols, total flavonoids, DPPH and FRAP for $V$. myrtillus (Wild 1, Wild 2) and V. corymbosum (Bluecrop, Elliot, Duke) which were collected in Romania. In this study, it was reported that wild blueberries had higher antioxidant activity than cultivated blueberries. In Italy, Giovanelli and Buratti (2009), collected V. myrtillus (lot 1 and lot 2) and V. corymbosum (Bluecrop, Goldtraube, Darrow and Patriot) fruits and made total anthocyanins, total polyphenols, DPPH and FRAP analyses. They reported that the wild blueberries had a high antioxidant capacity than the cultivated species. In addition to this, they found that the fruits of cv. Patriot showed the highest activity among the all cultivars. It can be said that the similar results were determined from our study for $V$. myrtillus and V. corymbosum.

Table 1 Results of statistical analyses showing the relationship of phenolic contents, flavonoid contents and anthocyanin with different blueberry species*

\begin{tabular}{|c|c|c|c|}
\hline Samples** & Total phenolics (mg GAE/g DS ${ }^{\dagger}$ ) & Total flavonoid (mg QE/g DS) & Total anthocyanin (mg Cyn/g DS) \\
\hline V. arc. ebh & $20.74 \pm 0.24^{\mathrm{g}}$ & $1.93 \pm 0.10^{\mathrm{c}}$ & $6.13 \pm 0.01^{i}$ \\
\hline V. arc. fy & $19.19 \pm 0.20^{\mathrm{f}}$ & $1.18 \pm 0.16^{\mathrm{a}, \mathrm{b}}$ & $3.30 \pm 0.00^{\mathrm{d}}$ \\
\hline V. arc. ep & $16.22 \pm 0.49^{\mathrm{e}}$ & $2.20 \pm 0.28^{\mathrm{d}}$ & $5.54 \pm 0.00^{\mathrm{h}}$ \\
\hline V. arc. sc & $11.54 \pm 0.63^{\mathrm{c}}$ & $2.16 \pm 0.46^{\mathrm{c}, \mathrm{d}}$ & $1.16 \pm 0.00^{\mathrm{b}}$ \\
\hline V. myrt & $20.06 \pm 0.33^{\mathrm{g}}$ & $2.67 \pm 0.01^{\mathrm{c}, \mathrm{d}}$ & $11.47 \pm 0.00^{\mathrm{j}}$ \\
\hline Dr & $13.49 \pm 0.56^{\mathrm{c}}$ & $0.74 \pm 0.46^{\mathrm{a}}$ & $4.43 \pm 0.01^{\mathrm{f}}$ \\
\hline $\mathrm{Bc}$ & $5.56 \pm 0.26^{\mathrm{b}}$ & $0.88 \pm 0.05^{\mathrm{a}}$ & $1.71 \pm 0.00^{\mathrm{c}}$ \\
\hline $\mathrm{Br}$ & $11.54 \pm 0.30^{\mathrm{d}}$ & $2.53 \pm 0.58^{\mathrm{d}}$ & $3.89 \pm 0.00^{\mathrm{e}}$ \\
\hline $\mathrm{Pt}$ & $15.88 \pm 0.57^{\mathrm{e}}$ & $1.67 \pm 0.16^{\mathrm{b}, \mathrm{c}}$ & $5.36 \pm 0.01^{\mathrm{g}}$ \\
\hline $\mathrm{Bj}$ & $8.329 \pm 0.362^{\mathrm{a}}$ & $5.650 \pm 0.372^{\mathrm{e}}$ & $1.03 \pm 0.003^{\mathrm{a}}$ \\
\hline
\end{tabular}


DPPH

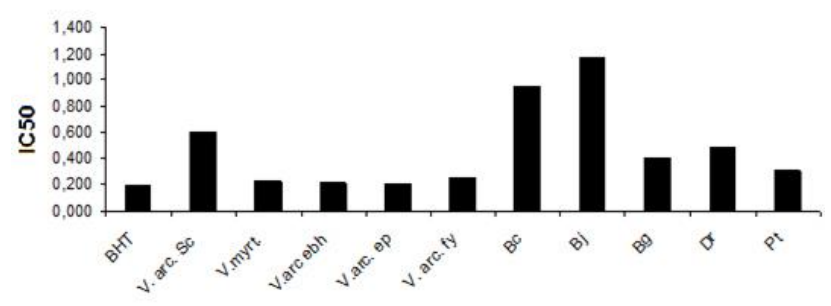

Figure 1 The results of DPPH for dry blueberry fruits

Table 2 Results of statistical analyses showing the relationship of FRAP and CUPRAC analyses for different blueberry species*

\begin{tabular}{l|cl}
\hline Samples & $\begin{array}{c}\text { FRAP } \\
(\mu \mathrm{mol} \mathrm{Fe} / \mathrm{g} \text { DS })\end{array}$ & $\begin{array}{c}\text { CUPRAC } \\
(\mathrm{mmol} \text { TEAC/g DS })\end{array}$ \\
\hline V. arc. ebh & $299.481 \pm 0.277^{\mathrm{h}}$ & $0.297 \pm 0.010^{\mathrm{g}}$ \\
V. arc. fy & $210.307 \pm 3.476^{\mathrm{f}}$ & $0.285 \pm 0.014^{\mathrm{e}, \mathrm{f}}$ \\
V. arc. ep & $250.401 \pm 3.540^{\mathrm{g}}$ & $0.274 \pm 0.007^{\mathrm{e}}$ \\
V. arc. sc & $130.719 \pm 9.899^{\mathrm{c}}$ & $0.143 \pm 0.013^{\mathrm{c}}$ \\
V. myrt & $346.115 \pm 6.039^{\mathrm{i}}$ & $0.304 \pm 0.008^{\mathrm{g}}$ \\
Dr & $150.277 \pm 5.990^{\mathrm{d}}$ & $0.120 \pm 0.002^{\mathrm{b}}$ \\
$\mathrm{Bc}$ & $90.021 \pm 2.960^{\mathrm{b}}$ & $0.090 \pm 0.005^{\mathrm{a}}$ \\
$\mathrm{Br}$ & $188.283 \pm 5.132^{\mathrm{e}}$ & $0.141 \pm 0.007^{\mathrm{c}}$ \\
$\mathrm{Pt}$ & $208.251 \pm 4.954^{\mathrm{f}}$ & $0.200 \pm 0.006^{\mathrm{d}}$ \\
$\mathrm{Bj}$ & $71.909 \pm 3.663^{\mathrm{a}}$ & $0.077 \pm 0.003^{\mathrm{a}}$ \\
\hline
\end{tabular}

*Values within column followed by different letters are significantly different $\alpha$ at $=0.01$

Our study showed that $V$. arctostaphylos berries had higher antioxidant contents than $V$. corymbosum, supporting the findings reported by Koca and Karadeniz (2009). According to results of Burdulis et al.'s (2009) study, $V$. myrtillus had high radical scavenging and antioxidant activity. Hasanloo et al. (2011) also examined the contents of antioxidant $V$. arctostaphylos fruits which were collected from different regions of Iran. They found that the fruits contained high anthocyanin $(1 \mathrm{mg} / \mathrm{g})$ and polyphenols (42.73 mg GAE/g), and also stated $V$. arctostaphylos berries were the source of antioxidants.

In the present study, the highest content of total polyphenols content obtained from the fruits of $V$. arctostaphylos collected from Borçka-Efeler-Bluberry Hill among all species their cultivars. Compared with other contents of total flavonoids and total anthocyanins V. myrtllus fruits were better than all others. According to FRAP and CUPRAC tests, V. myrtillus had higher activity than $V$. arctostaphylos. When radical scavenging capacity of these species considered, radical cleansing of V. arc. ep was better than the other species.

It was found that the contents of the total phenolic, total flavonoids and total anthocyanins of cv. Patriot, cv. Darrow and cv. Brigita were higher among $V$. corymbosum cultivars, respectively. In addition, cv. Patriot had a high level of activity of FRAP and CUPRAC analyses and it was better in view of radical scavenging capacity.

Overall, it can be said that when the fruits of $V$. myrtillus have higher antioxidant activity among all species, V. corymbosum cv. Patriot fruits have the highest antioxidant activity among the cultivars in this study.

\section{Acknowledgements}

The authors would like to thank the Artvin Çoruh University for its financial support of this research (2011.F10.02.08).

\section{References}

Al-Mamary M, Al-Meeri A, Al-Habori M. 2002. Antioxidantactivities and total phenolics of different types of honey. NutritionResearch 22: 1041-047.

Apak R, Güçlü K, Özyürek M, Karademir SE. 2004. Novel total antioxidant capacity index for dietary polyphenols and vitamins $\mathrm{C}$ and $\mathrm{E}$, using their cupric ion reducing capability in the presence of neocuproine: CUPRAC method. Journal of Agricultural and Food Chemistry 52: 7970-7981.

Atalay M, Gordillo G, Roy S, Rovin B, Bagchi D, Bagchi M, Sen CK. 2003. Anti-antigionic property of edible berry in a model of hemangioma. FEBS Letters 544: 252-257.

Benzie IF, Szeto YT. 1999. Total antioxidant capacity of teas by the ferric reducing/antioxidant power assay. Journal of Agricultural and Food Chemistry 47: 633-636.

Bunea A, Rugina DO, Pintea AM, Sconta Z, Bunea CI, Socaciu C. 2011. Comparative polyphenolic content and antioxidant activities of some wild and cultivated blueberries from Romania. Notulae Botanicae Horti Agrobotanici ClujNapoca 39(2):70-76

Burdulis D, Aarkinas A, Jasutien I, Stackevicien E, Nikolajevas L, Janulis V. 2009. Comparative study of anthocyanin composition, antimicrobial and antioxidant activity in bilberry (Vaccinium myrtillus L.) and blueberry (Vaccinium corymbosum L.) fruits. Acta Poloniae Pharmaceutica Drug Research 66(4): 399-408.

Chang CC, Yang MH, Wen HM, Chern JC. 2002. Estimation of total flavonoid content in propolis by two complementary colorimetric methods. Journal of Food and Drug Analysis 10: $178-182$.

Çelik H. 2004. Karadeniz için yeni bir meyve türü likapa (yaban mersini) (in Turkish). Ekoloji Magazin 1: 50-53.

Çelik H. 2005. Yaban Mersini (Likapa) Yetiştiriciliği (in Turkish). Hasad Yayıncilık.

Fuleki T, Francis FJ. 1968. Quantitative methods for anthocyanins. 2. Determination of total anthocyanin and degradation index for cranberry juice, J. Food Science 337883.

Giovanelli G, Buratti S. 2009. Comparison of polyphenolic composition and antioxidant activity of wild Italian blueberries and some cultivated varieties. Food Chemistry 112: 903-908.

Giusti MM, Wrolstad RE. 2001. Anthocyanins, Characterization and Measurement with Uvvisible Spectroscopy, In: Wrolstad RE (Ed.). Current Protocols in Food Analytical Chemistry, John Wiley\&Sons, New York, USA.

Gümüş C, Ölmez Z, Hangişi Ölmez G, Kalender Ç. 2009. Artvin'de yaban mersini (Vaccinium sp., Likapa) yetiştiriciliği eğitimi konulu $\mathrm{AB}$ projesinin tanıtımı ve projenin yürütülmesinde karşılaşılan güçlükler ve sorunlar (in Turkish). II. Ormancılıkta Sosyo-Ekonomik Sorunlar Kongresi, 19-21 Şubat, Isparta, 81-88.

Hasanloo T, Sepehrifar R, Hajimehdipoor H. 2011. Levels of phenolic compounds and their effects on antioxidant capacity of wild Vaccinium arctostaphylos L. (Qare-Qat) collected from different regions of Iran. Turkish Journal Biology 35: 371-37

Koca I, Karadeniz B. 2009. Antioxidant properties of blackberry and blueberry fruits grown in the Black Sea Region of Turkey. Scientia Horticulturae 121: 447-450

Pokorny J, Yanishlieva N, Gordon M. 2001. Antioxidants in Food, CRC Pres, USA. 
Prior RL, Cao GH, Martin A, Sofic E, Mc Ewen J, O’Brien C, Lischner N, Ehlenfeldt M, Kalt W, Krewer G, Mainland CM. 1998. Antioxidant capacity as influenced by total phenolic and anthocyanin content, maturity, and variety of Vaccinium species. Journal of the Agricultural and Food Chemistry 46: 2686-2693.

Riihinen K, Jaakola L, Karenlampi S, Hohtola A. 2008. Organspecific distribution of phenolic compounds in bilberry (Vaccinium myrtillus) and "northblue" blueberry (Vaccinium corymbosum $x V$. angustifolium). Food Chemistry 110: 156160.
Robards K, Prenzler PD, Tucker G, Swatsitang P, Glover W. 1999. Phenolic compounds and their role in oxidative processes in fruits. Food Chemistry 66: 401-436.

Slinkard K, Singleton VL. 1977. Total phenol analysis: Automation and comparison with manual methods. American Journal of Enology and Viticulture 28: 49-55.

Wu X, Cao G, Prior RL. 2002. Absorption and metabolism of anthocyanins in elderly women after consumption of elderberry or blueberry. The Journal of Nutrition, ProQuest Agriculture Journals 132(7): 1865-1871. 